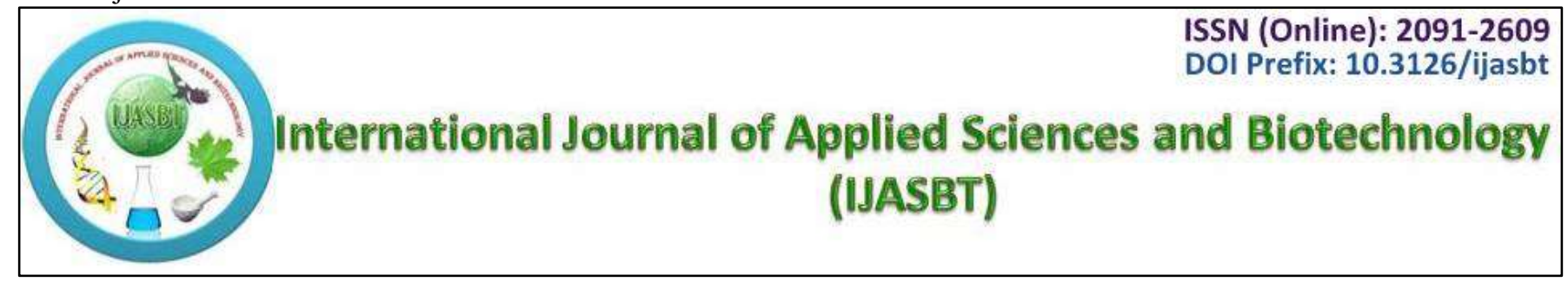

Research Article

\title{
Evaluation of Performances of Cowpea (Vigna ungiculata) Genotypes in Agronomy Farm of Lamjung Campus
}

\author{
Chandan Bhattarai ${ }^{1}$, Dinesh Marasini ${ }^{2}$, Prabin Dawadi ${ }^{1}$ and Sadkishya Aryal ${ }^{3}$ \\ ${ }^{1}$ Agriculture and Forestry University, Rampur, Chitwan, Nepal \\ ${ }^{2}$ Department of Agronomy, Agriculture and Forestry University, Rampur, Chitwan, Nepal \\ ${ }^{3}$ Institute of Agriculture and Animal science, Sundarbajar, Lamjung
}

\begin{abstract}
Seed to seed production experiments for cowpea (Vigna ungiculata) was conducted at Agronomy farm at IAAS Lamjung, and to compare production potentialities of given cowpea genotypes under the given sets of conditions. The treatment consists of two cowpea varieties viz. Prakash (Standard Check) and Malepatan (Local check) and four genotypes; IT 99K-573-2-1, IT 86F-2062-5, IT 93K-452-1, IT 98K-205-8. The experiment was conducted on RCBD design. .All other activities were carried out according to prepared working calendar almost from August 2016 to December 2016. Data collection were done for predetermined growth and other yield parameters and was analyzed using MSTAT. Major parameters were Grain yield, Seeds/plant, Pods/plant, plant height, pod length, harvest index and test weight. Result shows maximum grain yield and harvest index was found for Prakash (Standard Check).Plant height and Pods /Plant was found highest for IT 99K-573-2-1. Similarly highest seed weight was found for Prakash (Standard Check) and Seeds/Plant and Pod length was maximum for IT 86F-20625 .
\end{abstract}

Keywords: Cowpea; Yield attributes; Yield

\section{Introduction}

In Nepal, local cowpea (Kartike bodi, Makai bodi trailing type long duration local landraces) is grown as an intercrop with maize. Short duration varieties are grown as a mono crop in the spring season or after rainy season in September with supplemental irrigation. The estimated area, production and productivity are 6000 ha, 3660 MT and 610 $\mathrm{kg} / \mathrm{ha}$, respectively. Area and production are increasing every year because of availability of dual purpose (green pods as vegetable and dried pulse) short duration varieties.
Food and Agriculture Organization estimated that 5.4 million metric tons of cowpea grain were produced worldwide in the year 2008 and $91 \%$ of that production were from Africa (FAOSTAT, 2010). World cowpea production in 1994 was estimated at 3.53 million metric tons of which 1.75 million metric tons was produced in Nigeria (Adejumo, 1997). In West Africa, cowpea is second in importance after groundnut, with Nigeria accounting for over $70 \%$ of the total world production (Singh and Ajeigbe, 2002).

\section{Article may be cited as:}

C. Bhattarai et al. (2017) Int. J. Appl. Sci. Biotechnol. Vol 5(3): 382-385. DOI: http://dx.doi.org/10.3126/ijasbt.v5i3.18125

\section{$1 *$ Corresponding author}

Chandan Bhattarai,

Agriculture and Forestry University, Rampur, Chitwan, Nepal

Email: chandan.bhattarai2@gmail.com

Peer reviewed under authority of IJASBT

(C) 2017 International Journal of Applied Sciences and Biotechnology 
Cowpea (Vigna ungiculata), an annual legume, also commonly referred as Southern pea. Cowpea can be grown under rain-fed conditions and irrigation or residual moisture provided the temperature range are between $28^{\circ} \mathrm{C}$ and $30^{\circ} \mathrm{C}$ during the growing season (Dugje et al., 2009). Being deeprooted, cowpea performs well in sandy soils and is more tolerant to drought than soybean (Dadson et al., 2003). However, it does not tolerate excessive wet conditions or water-logging; thus best cowpea yields are obtained in welldrained sandy loam to clay loam soils with $\mathrm{pH}$ range between 6 and 7 (Dugje et al., 2009).

Cowpea is a staple component of the diet in several developing nations and a major source of protein to combat malnutrition in young children in lieu of expensive animal protein in such countries. Cowpea seeds contain about $25 \%$ protein, making it extremely valuable in areas where many people cannot afford proteinaceous foods such as meat and fish (Lephale et al., 2012). It has being regarded as poor man's meat (Ileke et al., 2012). The green and dry haulms are fed to livestock particularly in dry seasons when animal feed is scarce. It was further observed that of all the leguminous crops, cowpea appears to be one of the most important in sustainable soil fertility management (IITA, 1990), as it can fix up to $88 \mathrm{~kg}$ Nha-1 (Fatokun et al., 2002).

Indigenous as well as improved varieties of cowpea have been grown by the farmers in different agro-ecosystem in Nepal. There are very few varieties have been released for grain production in Nepal. So an experiment is designed to study the varietal performance of different genotypes of cowpea under upland condition in western mid hills of Nepal. The objective of this study therefore is to evaluate the growth, yield attributing characters and yield of cowpea genotypes.

\section{Materials and Methods}

\section{Location of Study}

A field trial was conducted at Agronomy farm of IAAS, Lamjung during 2015/2016. Coordinates of the site is $28^{\circ} 14^{\prime} \mathrm{N} 84^{\circ} 25^{\prime} \mathrm{E}$ and elevation of about 600 meter above sea level. The climate of the study area can be broadly postmonsoon, with a mono-modal rainfall which occurs between September and October. The other months of the year are usually dry. The mean temperatures during the months of September make the study location favorable to cultivation of cowpea. The soils of the study locations can be classified as alluvial deposits with texture ranging from sandy loam to sandy clay loam.

\section{Experiment Detail}

Experimental trials were carried out on RCBD design with 4 replications and 6 treatments. Two cowpea varieties (for checking) and four genotypes were used as treatments. Individual plots were facing East-West directions with an area of $2 m^{*} 2 m\left(4 m^{2}\right)$. Seeding was done at the spacing of
$40 \mathrm{~cm}(\mathrm{R}-\mathrm{R}) * 20 \mathrm{~cm}(\mathrm{P}-\mathrm{P})$ with 2 seeds. FYM was applied @ 6ton/ha and NPK@ 20:40:20 in each plot. Plant protection measures against aphid, pod borer and rodents insecticides and rodenticides were applied i.e.SAAF @2ml/liter and Cypermethrin (Contact) @1.5gm/liter.

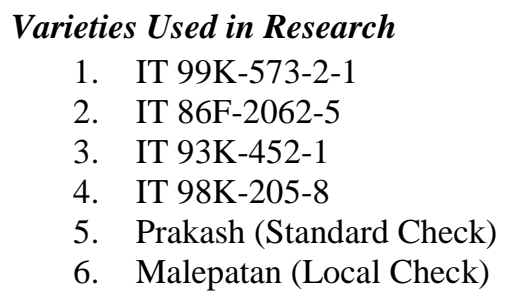

\section{Data Collection and Analysis}

Data on plant height, pod length, number of pods/plant, number of seeds/pod, test weight and other yield parameters were taken from two rows excluding the boarder ones to remove boarder effect. Data collected were analyzed using MSTAT.

\section{Results and Discussion}

Plant height at maturity was found to be significant among genotypes (Table 1). Maximum plant height of 99K-573-2$1(164.0 \mathrm{~cm})$ was significantly higher than other all other genotypes and minimum for IT $98 \mathrm{~K}-205-8(84.75 \mathrm{~cm})$. This variation might be attributed to the differences in the genotypes or might be due to environmental fluctuation. Similar results were reported by Ram et al., (1994).

Pod length was found to be highly significant with maximum IT $86 \mathrm{~F}-2062-5(21.00 \mathrm{~cm})$ and Minimum IT 99K$573-2-1(14.69 \mathrm{~cm})$. As compared to the tested genotypes check cultivars were observed relatively shorter (Table 1). Similar results were reported by Muhammad et al., (1994), who studied six different genotypes under medium rainfall conditions and reported significant variation for pod length among the genotype. That is the conformation of genotypic and environmental effect.

Pods per plant was found to be significant with maximum IT 99K-573-2-1 (18.50) and minimum for IT 98K-205-8 (12.25).Others are statistically at par with IT 98K-205-8 and Malepatan is intermediate with value of 15.75 (Table 1). Number of pods per plant is one of the phenotypic traits with high contributions to the genetic variability in legumes pigeon pea (Cajanus cajan L.) (Upadhyaya et al., 2007).

Seeds per pod of all genotypes was found to be insignificant with maximum value for IT $86 \mathrm{~F}-2062-5$ (12.75) and minimum for IT $98 \mathrm{~K}-205-8$ (11.75). Moreover this variation might be due to different genotypes or due environment which promote early maturity thus minimum time was available for seed setting and development. Similar results were reported by Muhammad et al., (1994) and Amanullah et al., (2000). Thiyagarajan and Rajasekaran (1993) found that plant height also affect seed per pod. 
Table 1: Effect of different genotypes on plant height at maturity $(\mathrm{cm})$, pod length $(\mathrm{cm})$, pods per plant and seeds per pod.

\begin{tabular}{lcccc}
\hline Genotypes & Plant height at maturity $(\mathbf{c m})$ & Pod length $(\mathbf{c m})$ & Pods per plant & seeds per pod \\
\hline IT99K-573-2-1 & $164.0^{\mathrm{a}}$ & $14.69^{\mathrm{b}}$ & $18.50^{\mathrm{a}}$ & 12.5 \\
IT 86F-2062-5 & $91.84^{\mathrm{d}}$ & $21.00^{\mathrm{a}}$ & $16.50^{\mathrm{ab}}$ & 12.75 \\
IT 93K-453-1 & $131.6^{\mathrm{b}}$ & $15.82^{\mathrm{b}}$ & $16.00^{\mathrm{ab}}$ & 12.00 \\
IT 98K-205-8 & $84.75^{\mathrm{d}}$ & $15.69^{\mathrm{b}}$ & $12.25^{\mathrm{c}}$ & 11.75 \\
Prakash & $125.3^{\mathrm{b}}$ & $15.38 \mathrm{~b}$ & $16.00^{\mathrm{ab}}$ & 12.5 \\
Malepatan & $111.7^{\mathrm{c}}$ & $15.90^{\mathrm{b}}$ & $15.75^{\mathrm{b}}$ & 12.5 \\
\hline CV (\%) & 6.25 & 9.06 & 10.55 & 9.24 \\
\hline
\end{tabular}

Table 2: Effect of different genotypes on grain yield (ton/ha), Harvest index and test weight (g).

\begin{tabular}{llll}
\hline Genotypes & Grain yield (Ton/ha) & Harvest index & Test weight $(\mathbf{g})$ \\
\hline IT 99K-573-2-1 & $0.5075^{\mathrm{c}}$ & $12.55^{\mathrm{c}}$ & $136.0^{\mathrm{d}}$ \\
IT 86F-2062-5 & $0.5275^{\mathrm{c}}$ & $14.46^{\mathrm{bc}}$ & $124.5^{\mathrm{e}}$ \\
IT 93K-453-1 & $0.5600^{\mathrm{c}}$ & $14.47^{\mathrm{bc}}$ & $168.5^{\mathrm{b}}$ \\
IT 98K-205-8 & $0.8800^{\mathrm{b}}$ & $19.95^{\mathrm{b}}$ & $163.5^{\mathrm{c}}$ \\
Prakash & $1.125^{\mathrm{a}}$ & $27.86^{\mathrm{a}}$ & $160.9^{\mathrm{c}}$ \\
Malepatan & $0.6300^{\mathrm{c}}$ & $14.99^{\mathrm{bc}}$ & $182.2^{\mathrm{a}}$ \\
\hline CV (\%) & 18.63 & 21.67 & 1.99 \\
\hline
\end{tabular}

Maximum grain yield was found for Prakash (1.1ton /ha) and intermediate was found at IT $98 \mathrm{~K}-205-8$ (0.88ton/ha).Lowest yield was found for IT 99K-573-2-1 $(0.5075)$. The peculiarity of genotypes is of great importance when we evaluate/ develop genotypes for stability. However, variation in yield was noted (Table 2), which may be attributed to climatic diversity and genetic makeup of the genotypes. Such variations in yield of different genotypes were also reported by Amanullah et al. (2000), Muhammad et al. (1994), Ram et al. (1994). They found significant differences in seed yield and showed positive relationship with seed pod-1, seed weight, plant height and pod length.

Harvest index was found to be significant with maximum for Prakash variety $(27.86 \%)$ and intermediate for IT 98K205-8 (19.95\%) followed by Prakash and others are statistically at par between IT 99K-573-2-1 and IT 98K205-8 (Table 2).

Test weight of the genotype was found to be highly significant with maximum value for Malepatan (182.2) followed by IT 93K-452-1, Prakash, IT 99K-573-2-1 and minimum for IT 86F-2062-5 (124.2). These differences in seed weight might be due to the time factor for the accumulation of assimilates in the seeds and differences in the genetic makeup of different genotypes. Acclimatization factor might also be responsible for higher seed weight. Similar variations were also reported by Amanullah et al., (2000).

\section{Conclusion}

From this research we all came to know about the performance of the various genotypes when compared to the released variety Prakash (Standard check) and Malepatan (Local check) on various growth yield attributing characters like harvest index, plant height, pod length, pods per plant, seeds per plant, grain yield, and test weight on given sets of same environment conditions and agronomic practices. We concluded that the released variety Prakash and Malepatan are superior in various parameters but some genotypes also performed well. Among genotypes IT 98K-205-8(IT 98K205-8) is comparatively superior to others. These variation may be due to genotypic, environmental and $\mathrm{G}^{*} \mathrm{E}$ interaction. This research could be effective strategy to recommend the superior genotypes to the farmers of Lamjung and also a means for crop improvement program.

\section{Acknowledgement}

We are thankful to Institute of Agriculture and Animal Science and Agriculture and Forestry University for their 
financial support and Assistant Professor Dr. Santosh Marahatta for his regular guidance.

\section{References}

Adejumo TO (1997). Identification, incidence, severity and methods of control of the causal organism of false smut disease of cowpea Vigna unguiculata (L.) Walp. PhD. Thesis. University of Ibadan, Ibadan, Nigeria

Amanullah, Hatam M and Ahmad N 2000. Performance and distinguishing characters of promising cowpea germplasm. Sarhad J of Agric 16(4): 365-369.

Dadson RB, Hashem FM, Javaid I, Joshi J and Allen AL (2003) Response of Diverse Cowpea Genotypes to Drought. (CD-ROM) Annual Meeting Abstracts. ASA, CSSA, SSSA: Madison, WI.

Dugje IY, Omoigui LO, Ekeleme F, Kamara AY and Ajeigbe H (2009) Farmers' Guide to Cowpea Production in West Africa. IITA: Ibadan, Nigeria. 20.

Fatokun CA, Tarawali SA, Singh BB, Kormarawa PM, Tamo M (eds) (2002) Challenges and opportunities for enhancing sustainable cowpea production. IITA. Ibadan, Nigeria

FAOSTAT (2010) Faostat. Retrieved12 May 2011 from http:// faostat. fao.org/ site/339/ default. aspx

Upadhyaya HD, Reddy KN, Gowda CLL, Singh S (2007) Phenotypic diversity in the Pigeon pea (Cajanus cajan) core collection. Genet ResourCrop Evol 54L 1167 1184. DOI: $10.1007 / \mathrm{s} 10722-006-9008-5$
IITA (1990) Manual for resistance to bacterial blight, virus and Striga under natural infestation in the West African; Grain legumes improvement work shop, IITA Ibadan Nigeria Pp: $270-273^{2}$.

Ileke KD, Odeyemi OO and Ashamo MO (2012) Insecticidal activity of Alstonia boonei De Wild powder against cowpea bruchid, Callosobruchus maculates (Fab.) [Coleoptera : Chrysomelidae] in stored cowpea seeds. International Journal of Biology 4(2): 125 - 131. DOI: 10.5539/ijb.v4n2p125

Lephale S, Addo-Bediako A and Ayodele V (2012) Susceptibility of seven cowpea cultivars (Vigna unguiculatus) to cowpea beetle (Callosobruchus maculatus). Agricultural Science Research Journals 2(2): 65-69.

Muhammad G, Ramazan CM, Aslam M and Chaudhry GA (1994) Performance of cowpea cultivars under rainfed conditions. J of Agric Res 32(1): 119-122.

Ram T, Ansari MM and Sharma TVRS (1994) Relative performance of cowpea genotypes in rainfed condition of Andaman and their genetic parameter analysis for seed yield. Indian J Pulses Res 7(1): 72-75.

Singh BB and Ajeigbe HA (2002). Improving cowpea-cereal based systems in the dry Savannas of West Africa. Production

Thiyagarajan K and Rajasekaran S (1993) Metro graph analysis in cowpea. Indian J Pulses Res 6(2): 145-148. 